\title{
Leading as Fugitives: the Case of Militant Groups in Nigeria's Oil Producing Communities
}

\author{
Beloveth Odochi Nwankwo* \\ University of Derby, UK \\ *Corresponding author: belovethodo@yahoo.com
}

Received February 01, 2015; Revised March 28, 2015; Accepted April 23, 2015

\begin{abstract}
The activities of militia leaders made the region the hot spot of resource based violence in Nigeria and Africa. It has been observed that militant groups and their leaders in Nigeria's oil producing states have gained prominence in recent times as there is hardly any week that their affairs are not discussed or reported in the polity. With emphasis on the context and objectives of militancy, the paper identifies the modus operandi of militia leaders in the Niger Delta. The article made use of secondary sources relevant to the topic and media reports on the situation in oil producing communities. The article maintains that the main reason militia leaders live like fugitives are to protect their goals from being endangered and also to evade possible arrest by the federal government. It would do the country more good to discover the sources of militancy, why people wake up and form militia groups.
\end{abstract}

Keywords: Niger Delta, Militancy, violence, conflicts

Cite This Article: Beloveth Odochi Nwankwo, "Leading as Fugitives: the Case of Militant Groups in Nigeria's Oil Producing Communities.” American Journal of Educational Research, vol. 3, no. 5 (2015): 599-603. doi: 10.12691/education-3-5-11.

\section{Introduction}

There is a growing recognition of militant groups and their leaders in Nigeria's oil producing states. These leaders of 'outlawed' groups have shown their determination and readiness to continue fighting for what they believe is right for their people and not necessarily what the state wants them to do or renounce.

Similarly, Nigeria's oil producing communities have witnessed series of turbulence arising from the confrontation between militant groups and the security forces loyal to the federal government. So far, Niger Delta affairs has been characterised by the politics of oil and issues of environmental sustainability as a result of corporate practices in oil producing communities.

This motivated the emergence of groups that always parade themselves as freedom fighters or mouth piece of the people in that region which largely contributes to Nigeria's economic survival. The region has been the locus of 'generalised ethnic and regional struggle for self determination since the 1990s in which violence is spearheaded by the youths (Osaghae et al, 2011:2; Aghalino, 2011). Observations and trends of militia activities in oil communities show that despite government's responses in various ways, leaders of these groups still wield considerable political and economic power in Niger Delta states. In fact, they are stakeholders as long as the Niger Delta affairs are concerned.

Osaghae et al (2011:2) argued that 'the negative impact of violence associated with youth led self-determination struggles in the Niger Delta and the urgent need to resolve the complex crises invite an in-depth examination of the youth, militias and self determination nexus in the region'. However, much has not been done on various issues concerning how militia leaders live as fugitives and at the same time lead their groups.

Militancy is not peculiar to Nigeria but that of Niger Delta continues to attract global attention due to geostrategic nature of the region in international economy. Aghalino (2011:2) attributed the violence in Niger Delta to the renewed call for self-determination and local control of oil resources by the people, and also to prevent the destruction of their environment. Some of the sources of environmental damage are gas flaring, oil spillage, which reduce farm yields and harm the health of residents who sometimes face the risk of blindness and fertility problems (Ndujihe, 2012:10). In most cases, the leadership role of commanders of liberation movements or militant groups in the Niger Delta is contested because government sees them as outlaws, people that must be stopped due to their activities that threaten oil production. In fact, they are always targeted by security operatives who are directed either to arrest them or shoot them at sight to deter others from participating in the act of militancy.

According to Onuoha (2006), militancy originated in February 1966 when a small group of Ijaw activists (the Niger Delta Volunteer Force) led by Isaac Adaka Boro, Sam Owonara and Nottingham Dick attempted to secede the Niger Delta region from Nigeria through the force of arms and proclaimed the Niger Delta a republic, but unfortunately for them, their insurgency was short-lived as it was crushed by federal troops within 12 days.

Olufemi Ayodele (2010:17) established an obvious link in Niger Delta with government's neglect of the Delta's 
development, like roads, schools, electricity, and health services all ended well inland before reaching coastal communities, thereby portraying a situation that confirmed the region's status as an economic backwater (Technical Committee Report on Niger Delta, 2008).

\section{The Context of Militancy in Niger Delta}

A militia refers to any group of people that are not professional soldiers but who have military training and have the capacity to act as an army (Falana, 2007). Militancy according to Osagahe (2011:19) 'refers to a combative and aggressive activism or engagement in struggles for identified causes'. Niger Delta militants are people that make politically related demands especially those that concern the politics of oil wealth and the release of leaders that agitate for these restive groups. We have revolutionary militant leaders and transformational militant leaders in the Niger Delta. Most times, they are concerned with what the government should do for the people and how the oil companies should empower the people to maintain their corporate social responsibility by making the benefit from their daily business of oil exploitation in their communities. The problem associated with militancy is that it exposes a society to danger, threatens human security and causes physical violence.

In Pakistan for example, 'the outbreaks of militant violence have become an all too familiar reality in Pakistan, affecting the safety and well-being of people and states far beyond the country's borders (Winthrop and Graff, 2010:7). Just like in Pakistan where the overall level of violence increased, and militant groups also multiplied and developed complex relationships with each other (Winthrop and Graff, 2010), various groups in the Niger Delta established a common objective of coercing the state to respond to their goals. The capacity they have is usually reinforced by their ability to acquire arms and adopt the instrument of force to achieve their objectives. There is hardly any militant group that does not have a leader or a form of command structure for effective coordination of its activities. In essence, militia groups have leaders, and they are even sometimes organised and more equipped than security forces.

The perennial militancy in the Niger Delta region has been described as 'a consequence of injustice and inequity in which resources and values are distributed' (Karim, 2013:343). Most scholars have cited a lot of issues that led to youth restiveness and proliferation of militant groups in the region. According to Olayode (2012:285), most self determination organisations emphasise the collective identity of specific groups and are willing to use confrontation to achieve their goals. Self determination "is seen as the right or freedom of a people that are subordinated, oppressed, dominated, it connotes the desire of a people for self existence, self management, self development and sovereignty over resources” (Osaghae et al, 2011:8). However, Olayode argued that self determination by a group in a heterogeneous nation could be dangerous to other groups if that country's wealth is generated from that region (2012).

In terms of state response to ethnic militia in the country, failure to address various forms of injustice and state's confrontational or antagonistic approach seems to aggravate the crisis of militancy. For instance, Falana (2007:226) writes that 'following the launching of the Ogoni Bill of Rights in 1993, the Babangida junta enacted the Treason and Other Treasonable Offences Decree, which prescribed the death penalty for the uttering of word, display or publication of any material capable of breaking up Nigeria or any part thereof.' By implication, the law further heightened tensions and worsened Nigeria's human rights records as most people were victimised rather than addressing the perceived injustice in some parts of the country. However, the law did not stop most of self determination movements in the Niger Delta from executing their objectives.

The Ogoni Bill of Rights drafted in 1990 saw internal autonomy as the way out of their marginalisation; they demanded among other things, a political control of their affairs, the right to control and the use of Ogoni economic resources for their development, while their struggle was championed by Ken SaroWiwa whose writings and nonviolent actions enlightened the world on the issues involved, (Olayode, 2012). The Movement for the Survival of Ogoni People was able to take their case to the United Nations, and this had an adverse effect on the government of Nigeria (Olayode, 295:2012). The plunder and terror suffered by the Ogoni is linked to the curse of oil wealth in the region called Niger Delta which has similar marginalisation like the West Papuans based oil related policies that do not necessarily benefit the people (Nixon, 1996).

Also, April 122002 was the day when Olusegun Obasanjo administration sent a bill to the National Assembly to ban the activities of ethnic militia groups in Nigeria especially those in the Niger Delta like the Egbesu Boys of Africa and the Movement for the Emancipation of Niger Delta (Douglas and Ola, 2007). This was to silence all agitating groups in the country. Many years of neglect of underdevelopment of oil producing communities are some of the factors that motivated militancy against the state. The problem became complicated when they graduated from freedom fighters or agitators to criminal networks that specialise in the abduction of people and demand for ransom that they prefer to receive at desired locations.

From the foregoing, the theoretical explanations of militancy and government's response to silence them are embedded in hostility perception which makes Catildi (2011:29) to state that hostility perception theory gives the impression that the perception of the other is hostile toward oneself or one's own group; and the control balance - deviance theory which is anchored on the amount of control people are subjected to, and exercise that influences their type of deviant behaviour (Tittle, 1995). Here, the militia leaders are seen as deviants and conspirators by the government while militants themselves see the government and security operatives as oppressors. According to Olayode (2012) the main issue in contention is the right of people to determine their own destiny. And this self determination interest is what the government describes as conspiracy or unrealistic goal that must be prevented by all means. Examples are the confrontations between government and militants in the creeks of Niger Delta and the establishment of the joint security task force to discourage mutants and compel them to abandon their objectives. People are cautioned by the 
security operatives to raise their hands whenever they get to check points.

The hostility perception on the part of government is premised on the demand for resource control and compensation by the people in oil producing communities, while the effects of oil exploration and exploitation are the drivers of youth restiveness which motivates kidnapping of oil workers (Ozekhome, 2007:239). To the people of Niger Delta, the increases in oil exploration and exploitation have not increased the well being of the people (Udegbunam, 2013). This means that the militia leaders and their boys want positive impact of oil resources in their communities. thus:

Evoh (2009:43) has highlighted the context of militancy,

Nigerian youths harbour a high sense of deprivation, especially against the Nigerian state, political elite and oil companies operating in the country. The youths, particularly those in oil-producing communities and those in communities host to oil pipelines share in the single motive to wrest oil resource rent by force.

It is this sense of deprivation that motivates youths to carry arms and pay homage to a militant leader who assures them of recognition and wealth, because the ability of non-state armed groups to convince young people to join depends of their ability to convince them on the supposedly benefits of belonging to that group. Osaghae et al (2011:16) also noted that Niger Delta minorities have been disadvantaged within the Nigeria state project, neglected and marginalised.

The continuous struggle of Niger Delta youths was driven by the inspiration they received from Ogoni struggle and the execution of Saro Wiwa who was convicted and sentenced to death by the Civil Disturbance Tribunal in February 1995 and later hanged to death on November 10, 1995 (Olayode, 2012:296). His untimely death has been a motivation to the youths who believe that their destiny as a people is in their hands. Unfortunately, the obvious underdevelopment of oil producing communities and the rising unemployment crisis rather makes it difficult for both militia leaders and the new recruit to see the negative side of militancy.

The problem is that most times, militia group leaders often capitalise on the poor delivery of corporate social responsibility of oil companies to form the groups with the aim of using force on both government and the oil companies' speed up development in the region. They also accuse government of not taking the issue of unemployment seriously while most non-oil producing cities are being developed with the oil revenue from Niger Delta.

By implication, this increase the possibility of recruiting bale bodied men into militancy.

The Objectives of the Militia Groups

Both militia leaders who formed restive groups and some Niger Delta leaders seem to have similar interests geared towards developing their communities. The objectives are:

i) A restructuring of the Nigerian state and it's federalism in such a way that will guarantee: Self determination; political autonomy and fiscal control

c. True federalism

d. Community control over development strategies e. Protection of land, dignity, culture, freedom, environment and natural resources of the Niger-delta people

f. The right of states and communities to resource control

ii) A broad based development programme to transform the region.

iii) A political autonomy that guarantees political participation, representation and community participation in resource management,

iv) Implementation of a minimum of 50 per cent derivation

v) Immediate clean up of spills in oil producing communities

vi) Actualisation of Self determination and resource control through a sovereign National Conference of ethnic groups (Osaghae et al, 2011:22-23)

Although militants are not only seen as dissidents but also the enemies of Nigeria, Asari Dokubo's ally Tari Thomas stated that "these people are not militants, they are men agitating for their rights, but they have been pushed to the wall, it was the federal government that pushed these people to the wall, and militancy is not the character of Ijaw people (The Week, 11 June 2007:24). The people of Ijaw are seen as peaceful people who want economic and environmental justice, and that is why some of them lead what they call liberation struggle. Leaders of militia groups in the region have one common ideology: that the confrontation by the security operatives may injure the people either psychologically or physically, but cannot hurt or eradicate the struggle.

\section{Modus Operandi of Militia Leaders}

Militancy in Nigeria has always been characterised by the activities of armed groups in oil producing areas of Niger Delta. These groups recruit jobless non-educated and educated youths turning them into local gangsters and oppressors in their locality. Their strategy is to motivate their boys to heighten tension by carrying out unprovoked attacks on security operatives that are saddled with the responsibility of maintaining law and order in the area.

Niger Delta militants usually begin their activities by recruiting and initiating those interested in their objectives into the act of militancy. They organise them in groups and map out plan of action and coverage areas or areas of influence. Militant leaders in the region do not always operate everywhere. They have their strongholds and communities where their safety is guaranteed. This makes them to live as fugitives to avoid arrest by the authorities of the state.

The monopoly of the instrument of violence was whisked away by the activities of various non-state armed groups in Nigeria, and also fuelled by the proliferation and activities of cult groups which sometimes mark the starting point of militancy / militia groups. Cult groups and gangs also have similar ideological orientation because most of them were originally formed to protest against social injustice but the only difference is that membership of cult groups is more secret or hidden than that of militia groups; but while oath taking to guarantee allegiance and secrecy in the group is a major practice in cults, not all militia groups do this, while both cults and 
militia groups acquire arms and use violent means to achieve their group objectives (Osaghae et al, 2011:21). The problem is that they deny themselves liberty as they live like fugitives, minding where they go and who they tell their movement.

Apart from bombing oil pipelines and sending of email messages to media (Akinfenwa, 2007), they issue ultimatums to government through their spokespersons and either warn government to address their demands or they execute the threats. In the history of Niger Delta, there are many non-state armed groups and with different leaders but only few leaders of militants or freedom fighters that had a significant command structure and bold leadership styles in confronting the state. Asari Dokubo and Isaac Adaka Boro, and also self determination advocate Ken Saro Wiwa were just the few of such personalities. In militia groups, most of the leaders live like fugitives by avoiding public places and sending their boys on errands.

Two factors made the government to act the way it did: sustenance of democracy, and protection of territorial integrity with the monopoly of force ideology.

It is on record that when the federal government under Obasanjo administration arrested Asari Dokubo, the leader of NDPVF and charged him to court for what the government described as treasonable act against the state, his followers made failed attempts to effect his release, but were not deterred as Dokubo's close ally Tari Thomas threatened that they invoked the gods. According to him: "I will go to the cell where Asari Dokubo is with 50 baskets of snakes and release him; any man I meet there will go with it; anybody who would want to counter us will be confronted by the snakes; if the mandate expires and nothing was done we are going there to take this man by force" (The Week, 11 June 2007:24). This shows that Asari is a leader that cannot be left to die or suffer alone without his group members making efforts to ensure his freedom. The Yar'Adua administration later released Asari Dokubo when he took over power after the 2007 elections. This did not stop militia groups from agitating for resource control.

In 2012, the leader of Movement for the Liberation of the People of the Niger Delta (MLPND), Dan Anderson described the killing of Southerners by Boko Haram as unnecessary provocation and threatened to give directive to his boys to commence attacks on major oil installations and military establishments (Onukwugha, 2012).

In a similar development, precisely on November 2, 2012, the Movement for the Emancipation of Niger Delta (MEND) issued serious threats on the consequences of its fighters using technological warfare if the Federal Government accepted to demands made by the Boko Haram Islamist sect members without releasing their leader, Henry Okah and other members of the group held captive and accused of treasonable offence; and that with its acquisition of technological know-how, the group's renewed onslaught will affect most parts of the country especially the oil and nonoil sectors (Nigeria Daily Post, 2012). During this period, the influence of most militant leaders and others held captive made militia groups to intensify their attacks on military bases and oil installations in the region by. For example, before the members of the Movement for the Liberation of the People of the Niger Delta (MLPND) embarked on attack of oil workers and oil installations, they warned through their leader that: "We are on ground. What we will do this month end will be drastic. We started this struggle and it has been found out that the system is not working. We will shake this system because we want the federal government to give us our fare share of the national cake (Onukwugha, 2012:1).

Names of Some Militants that Participated in the Niger Delta Amnesty Programme:

The proclamation of amnesty, which meant unconditional pardon of militants willing to surrender their arms in 2009 by President Yar'Adua greatly polarised militant groups that did not want to negotiate with the government. The government succeeded in criminalising militancy through the amnesty exercise that sought to collect their illegal arms and demobilise the repentant militants. By implication, we not have exmilitants or repentant militants and unrepentant militants, actively involved in the struggle till date.

Some of those that participated in the struggle as militia leaders before the national amnesty are: Asari Dokubo, Ateke Tom, Fara Dagogo, Government Ekpemupolo, Mafimisebi Othello and the Gwame Boys of Ilaje. The Young Shall Grow, Commander Ngologolo, Toroma, Commander Pius, Peace Advocate, Edward Youdowei, Commander Area, Osie Clever, Commander Ayaye (Udegbunam, 2013).

Most of these people worked with their group members to discourage the government from controlling the oil wealth. While NDPVF, MEND, NDPLM and others adopted violent confrontation of the security forces, MOSOP was a non-violent liberation movement led by Saro Wiwa to peacefully challenge state and corporate practices in their communities which are inimical to development and health of the people.

The containment measure adopted by government was the formation of the joint security task force to embark on operations that would curb the activities of militia leaders. The government also sponsored media jingles to convince members of militia groups to renounce their nefarious activities even when their leaders threatened them with punishment. While the ex-militants were in the creeks, they fought against rival factions whose interests did not tally with theirs as they believed in the existence of incompatible goals.

\section{Prospects of Militancy}

The influence of militancy on political leadership in Nigeria cannot be overemphasised. In the Niger Delta, most militant leaders became competitors in the electoral process and even joined political parties. The leader of Niger Delta People Volunteer Force, Asari Dokubo was able to join the Action Congress of Nigeria (ACN) and became a stakeholder both in his state Rivers and in Nigeria where he has the habit of commenting on pressing national issues namely, insecurity, elections and the relationship between northerners and southerners. Some repentant militants have been able to get contracts on securing various oil installations across the Niger Delta and would likely get more contracts on community vigilante in future. 
The leadership style of some militant group leaders have made it more complex for them to even consider negotiating with the state or disarm their fighters. The resultant effect has been internal displacement in communities and trauma arising from militarisation and exchange of gunfire between militants and soldiers.

In October, 2009, one of the notorious militant groups, the Movement for the Emancipation of the Niger Delta (MEND) announced an indefinite ceasefire to allow peace negotiation with the government to proceed, and other militant groups also began to disarmed but this was partial disarmament. It is not disputable that the violence in the region and activities of militia leaders show that both the National Amnesty Programme and conflict interventions in the Niger Delta were seen as being haphazard and uncoordinated (Onuoha, 2005).

Though the repentant or ex-militants are now stakeholders in the maritime and pipeline security, the unrepentant militants would create more threats of insecurity in the region unless the government takes concerted action in resolving the issues that motivate militancy. It is possible that repented militia leaders would easily re-arm and mobilise their former boys the moment government stops paying their allowances or fails to play her role as expected by the repentant militants.

\section{Conclusion}

This article has examined the leadership of militia groups by influential militants. The proclamation of amnesty in 2009 by the federal government may have deescalated the armed conflict in the Niger Delta, but it has not succeeded in disarming all militia group leaders who seem not to be comfortable with life outside the creeks. The foregoing shows that it is not enough to assert that militia groups are "unlawful, unruly and a source of terror, intimidation and death" as stated by Ozekhome (2007:243), which the government strongly believes in. It would do the country more good to discover and address the sources of militancy, why people wake up and form/lead groups and also the motivations that make youths join restive or militia groups.

Observations show that no militia group can function successfully without having an influential leader who is not only capable of carrying the group along but also take decisive and risky actions. Despite the reality that militia activities are treasonable, they are not deterred by imminent charges when apprehended. The doggedness of these groups even though some their member are now called ex-militants shows that any organised group that has a formidable leadership can achieve its objectives. One thing that makes militia leaders to live fugitive lifestyle is to avoid arrest by government which may truncate their objectives. This is because the arrest of any militant leader would greatly affect the group negatively even though such arrest cannot eradicate militancy completely.

\section{References}

[1] Aghalino, S. O. (2011), 'Oil and cultural crisis: the case of the Niger Delta', Africana 5 (1): 1-21.

[2] Cataldi, R. (2011), 'Clash of perceptions: hostility perception and the US-Muslim world relationship', in Journal of Peace, Conflict \& Development - Issue 18: 27-46.

[3] Douglas, O. and Ola, D. (2007), 'Nourishing Democracy, Nurturing Diversity: Ethnic Militnacy as Resisteance Politics in Nigeria, in Babawale, T. (ed.), Urban Violence, Ethnic Militias and the Challenge of Democratic Consolidation in Nigeria, Lagos: Institute for Media and Society.

[4] Evoh, (2009), 'Green crimes, petro-violence and the tragedy of oil: the case of the Niger Delta in Nigeria', In-Spire Journal of Law, Politics and Societies 4 (1): 40-60.

[5] Falana, F. (2007), 'Democracy, Constitutionalism and the Phenomenon of Ethnic Militias', in Babawale, T. (ed.), Urban Violence, Ethnic Militias and the Challenge of Democratic Consolidation in Nigeria, Lagos: Institute for Media and Society.

[6] Karim, A. A. (2013), 'Reflections on Security Sector and Conflict Management in Nigeria's Fourth Republic', in Albert, I. O. and Eselebor, W. A. (eds.), Managing Security in a Globalised World, Ibadan: John Archers Publishers.

[7] Ndujihe, C. (2012), 'Oily death: how Nigeria short - changed oil producing areas', Saturday Vanguard, 31 March.

[8] Nigeria Daily Post (2012), “MEND want Henry Okah Released before talks with Boko Haram or there will be serious consequences", 3 November, Available at: http://dailypost.com.ng/2012/11/03/mend-demands-release-henryokay-talks-boko-haram-will-serious-consequences/

[9] Nixon, R. (1996), 'Pipe dreams: Ken Saro-Wiwa, environmental justice, and micro-minority rights', Black Renaissance 1:1.

[10] Olayode, K. (2012), 'Self-Determination, Ethno-Regional Organisations aand Conflicts in Nigeria since 1960', in Ogbogbo, C. B. N., Olaniyi, R. O. and Muojama, O. G. (eds.), The Dynamics of Intergroup Relations in Nigeria since 1960, Ibadan: Department of History, University of Ibadan.

[11] Onukwugha, A. (2012), 'Niger Delta militants warn Boko Haram, threaten oil installations. Leadership online 9 January. Available at http://allafrica.com/stories/201201092263.html

[12] Onuoha, G. (2006), "Contextualising the Proliferation of Small Arms and Light Weapons in Nigeria's Niger Delta” Africa Security Review, Vol 15 No 2.

[13] Osaghae, E., Ikelegbe, A., Olarinmoye, O. and Okhonmina, S. (2011), Youth militias, self determination and resource control struggles in the Niger Delta, CODESRIA Research Reports: NO. 5, http://www.codesria.org/IMG/pdf/CDP_Nigeria2-2.pdf

[14] Ozekhome, M. (2007), 'Ethnic Militias and the Nigerian State: The Challenges before Civil Society', in Babawale, T. (ed.), Urban Violence, Ethnic Militias and the Challenge of Democratic Consolidation in Nigeria, Lagos: Institute for Media and Society.

[15] The Week, (2007), "We'll release Asari Dokubo by force”, vol. 25 no.19, 11 June.

[16] Tittle, Charles R. (1995), Control balance: toward a general theory of deviance, Boulder, CO: Westview Press.

[17] Udegbunam, K. C. (2013), 'Peacebuilding or Pacification: A Critique of Nigeria's Post - Amnesty Programme for Ex-Militants in the Niger Delta Region', in Isumonah, V. A., Oyebode, M. O. and Adams, A. (eds.), Nationalities, Identities and Terrorism: The Nigerian Experience. Ibadan: John Archers Publishers Ltd.

[18] Winthrop, R. and Graff, C. (2010), Beyond Madrasas Assessing the links between education and militancy in Pakistan, Center for Universal Education, Working Paper no.2. 